\title{
Bioactive Phytochemicals from Mercurialis spp. Used in Traditional Spanish Medicine
}

\author{
José Blanco-Salas ${ }^{1}$ (D), Francisco M. Vazquez ${ }^{2}$, María P. Hortigón-Vinagre ${ }^{1, *}$ and \\ Trinidad Ruiz-Tellez ${ }^{1}$ (D) \\ 1 Department of Vegetal Biology, Ecology and Earth Science, Faculty of Sciences, University of Extremadura, \\ 06071 Badajoz, Spain \\ 2 Department of Forest Production and Biodiversity, Institute of Research Agrarian Center La \\ Orden-Valdesequera, Scientific and Technological Research Center of Extremadura (CICYTEX) A5 Km 372, \\ 06187 Guadajira, Badajoz, Spain \\ * Correspondence: mahortigonv@unex.es; Tel.: +34-924-289300 (ext. 89052)
}

Received: 8 April 2019; Accepted: 27 June 2019; Published: 28 June 2019

\begin{abstract}
Plants from the genus Mercurialis have a long history of use as herbal remedies in traditional Spanish medicine. The growing interest in the conservation of knowledge related to biodiversity has encouraged us to review the bioactive phytochemicals from the four most widespread Mercurialis species in the Iberian Peninsula (M. annua L., M. ambigua L., M. perennis L., and M. tomentosa L.). First, the medicinal uses of these four species throughout Spain were compiled, and then a bibliographical search on their chemical composition was conducted in an attempt to justify their reported traditional uses. We found that most of the medicinal uses of Mercurialis spp. are supported by scientific evidence. This includes its antidiabetic and antihypertensive properties attributable to the flavonoid rutin and narcissin, respectively; its benefits in the treatment of skin dark spots, attributable to mequinol; and its anti-inflammatory activity, attributable to scopoletin, kaempferol, squalene, and cycloartenol. This review contributes to the validation of the medicinal uses of Mercurialis spp. in Spain and provides some new avenues for further investigations on the biological activity of this interesting medicinal plant.
\end{abstract}

Keywords: bioactive phytochemicals; Mercurialis spp.; traditional Spanish medicine

\section{Introduction}

The genus Mercurialis L. belongs to the Euphorbiaceae family. In Spain, it is represented by seven species (Mercurialis annua L., Mercurialis ambigua L., Mercurialis perennis L., Mercurialis huetii Hanry, Mercurialis tomentosa L., Mercurialis elliptica Poir., and Mercurialis reverchonii Rouy) [1]. The most widespread species are M. annua, M. ambigua, M. perennis, and $M$. tomentosa. The distribution of other species are being reduced to endemic areas [2].

Mercurialis spp. have been used since ancient times in traditional Spanish medicine. For example, in the Middle Ages, infusions made from Mercurialis spp. aerial parts were used to treat constipation, bronchitis, rheumatism, gout, and gynecological disorders, as well as to relieve swellings [3,4]. Today, Mercurialis-based remedies are used for inflammation, poor healing wounds, and sores. In Spain, the traditional uses of Mercurialis spp. include the treatment of high blood pressure, high blood sugar levels, and skin pigmentation disorders [5]. The fresh parts of Mercurialis are poisonous and their consumption has been reported to cause nausea, vomiting, and hemorrhagic inflammation of the digestive system and of the kidneys in mammals [6,7].

In 2014, the Spanish Ministry of Environment took the initiative of compiling all traditional knowledge relative to biodiversity, under Phase I from the inventory following the 42/2007 Law. 
The species M. апnua, M. ambigua, M. perennis, and M. tomentosa were included in the Phase II of this inventory published in 2018 [8,9].

Several studies characterizing the chemical composition of Mercurialis spp. have already been published [5,10-19]. Here, we reviewed the chemical composition of the four aforementioned species in order to elucidate which phytochemicals could be the basis of the claimed therapeutic activity of Mercurialis in Spanish folklore.

\section{Results}

\subsection{Mercurialis spp.: Botanical Description, Chorology, and Variability}

Mercurialis is a genus of herbaceous plants belonging to the Euphorbiaceae family that grow in ruderal lands and grow less so in forests. In Spain, seven species have been described, most of them with a limited distribution, except for the most widespread M. annua/M. ambigua (considered the same plant by popular knowledge, and difficult to differentiate from a taxonomical point of view [1]), M. tomentosa and M. perennis, whose distribution is shown in Figure 1. M. annua and M. ambigua are annual herbs which grow in urban areas or modified agricultural fields. M. tomentosa is a shrub, frequent at the edges of routes with calcareous soils. In contrast, $M$. perennis is a perennial herb that has a perennial rhizome system and is primarily found in shady woods (mainly oak and beech) [1].

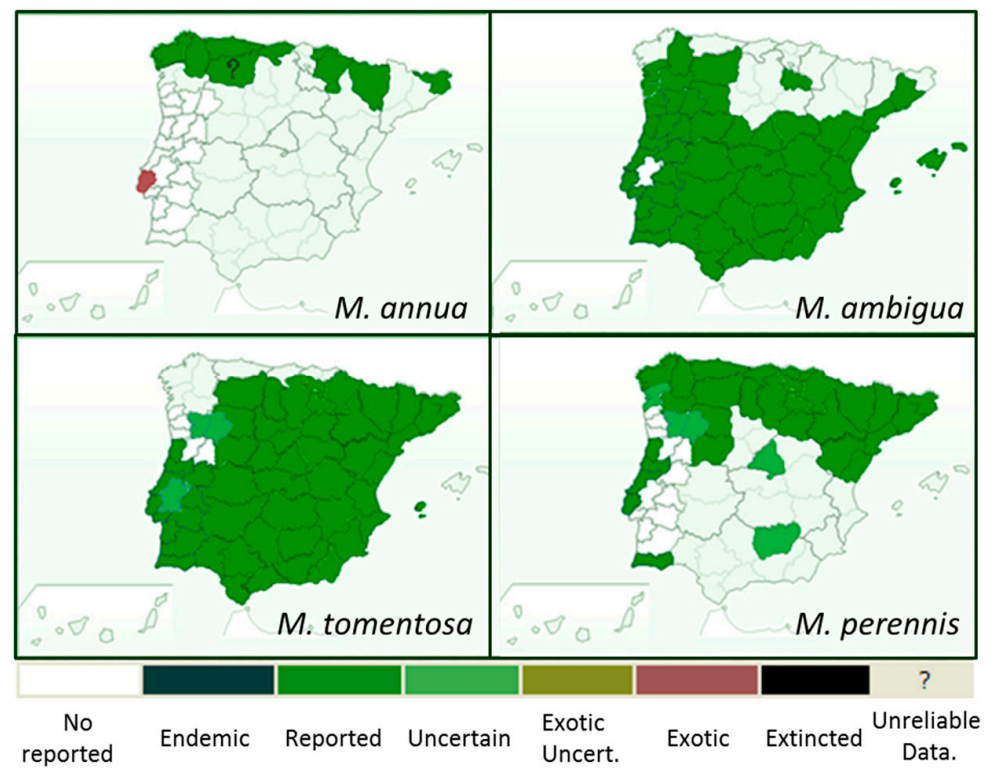

Figure 1. Distribution of Mercurialis annua, Mercurialis ambigua, Mercurialis tomentosa, and Mercurialis perennis in the Iberian Peninsula (https://www.bioscripts.net/).

Mercurialis spp. are dioecious, rhizomatous to annual herbs. They can be glabrous or densely hairy. The quadrangular stalk has simple leaves, bistipulate and opposite on a short petiole. They can reach a length up to $40 \mathrm{~cm}$. Unisexual flowers grow in different plants (dioecious species). Male spikes arise from the axils of the middle and upper leaves, the inflorescence generally extending beyond the leaves. Male flowers sessile or shortly stalked on pedicels $1-2 \mathrm{~mm}$ long, $4-5 \mathrm{~mm}$ across, consisting of three ovate-acuminate, concave, green glabrous segments, and 8-28 stamens. Female inflorescence is also axillary, shorter than the male, and usually bear 2-6 flowers, each of them with three sepals and one pistil. Hirsute, oval fruits, $5 \mathrm{~mm}$ in size [1]. 


\subsection{Mercurialis spp.: Ethnobotanical Uses}

Mercurialis spp. have been widely used in traditional Spanish medicine, despite being considered toxic plants for humans and animals [20-22]. A summary of the medicinal uses of Mercurialis spp. is shown in Table 1.

In their Dictionary of Natural History in the Canary Islands, Viera and Clavijo reported on the use of M. аппиa as a laxative [23]. Its juice was also widely used as a purgative in the Spanish steppe areas [24]. The laxative activity of Mercurialis has been reported for the four species addressed in this review. For example, in Cataluña, balls of crushed leaves from M. annua/M. ambigua, mixed with olive oil, were used as suppositories in case of constipation [25]. A decoction of the dried [26] or fresh leaves [25,27-29] of M. annua/M. ambigua was also used for constipation in Huesca [26], Gerona [25,28,29], and Castellón [27]. In Valencia, the dried leaves were reported to be less effective than the fresh ones [30]. The blossomed stems of M. tomentosa were also traditionally used for this purpose in Albacete (Castilla la Mancha) [31,32]. They were also reported in the same region as an effective remedy for diarrhea [32]. In Valencia, an infusion of the aerial parts was traditionally used as a laxative, and in Castellon, it was used as a strong laxative when mixed with Cassia angustifolia [27]. In Valencia, the intake of an infusion with honey at fast every morning was said to act as a mild laxative [30].

Table 1. Traditional uses of Mercurialis spp. in Spanish medicine.

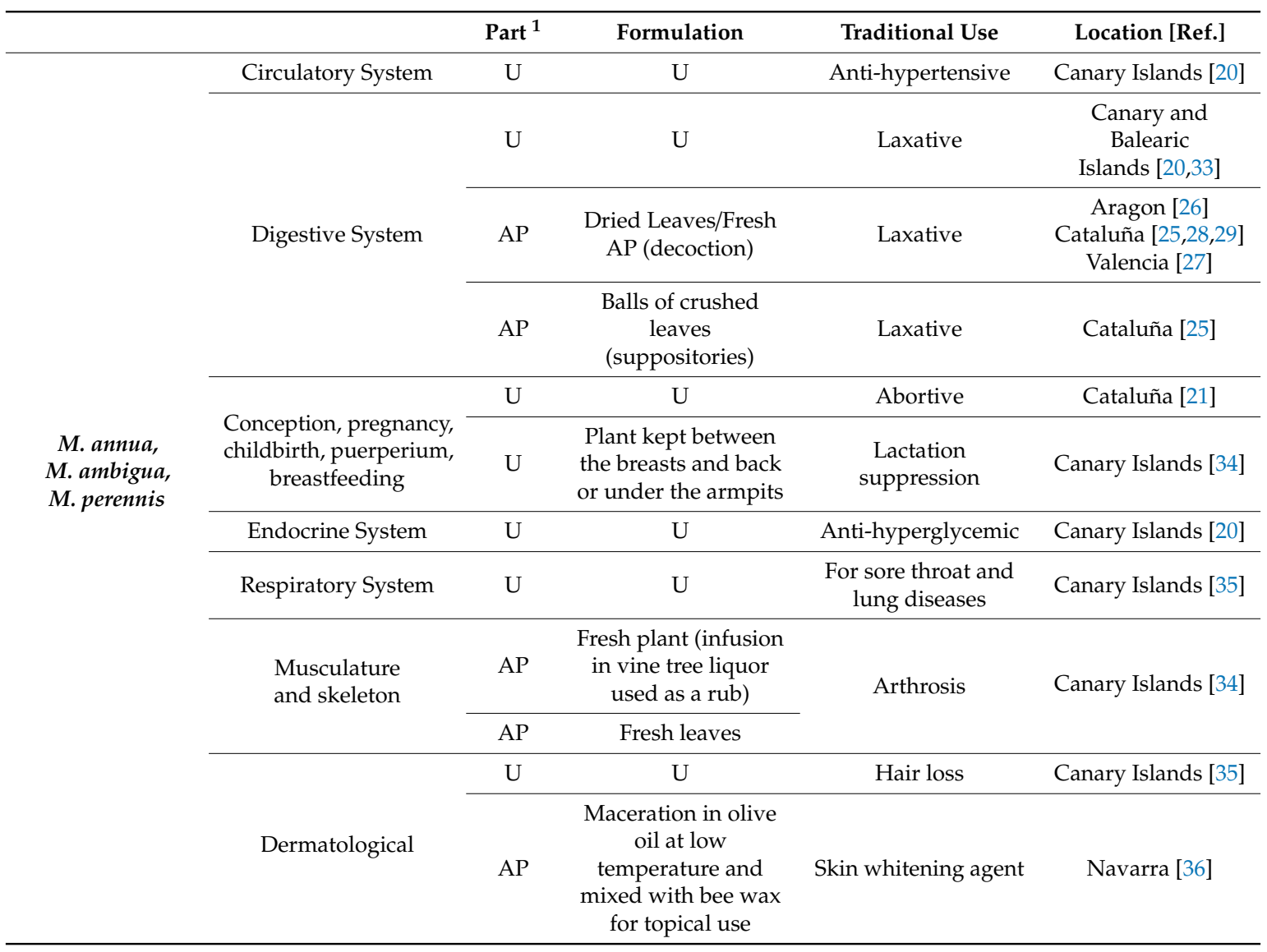


Table 1. Cont.

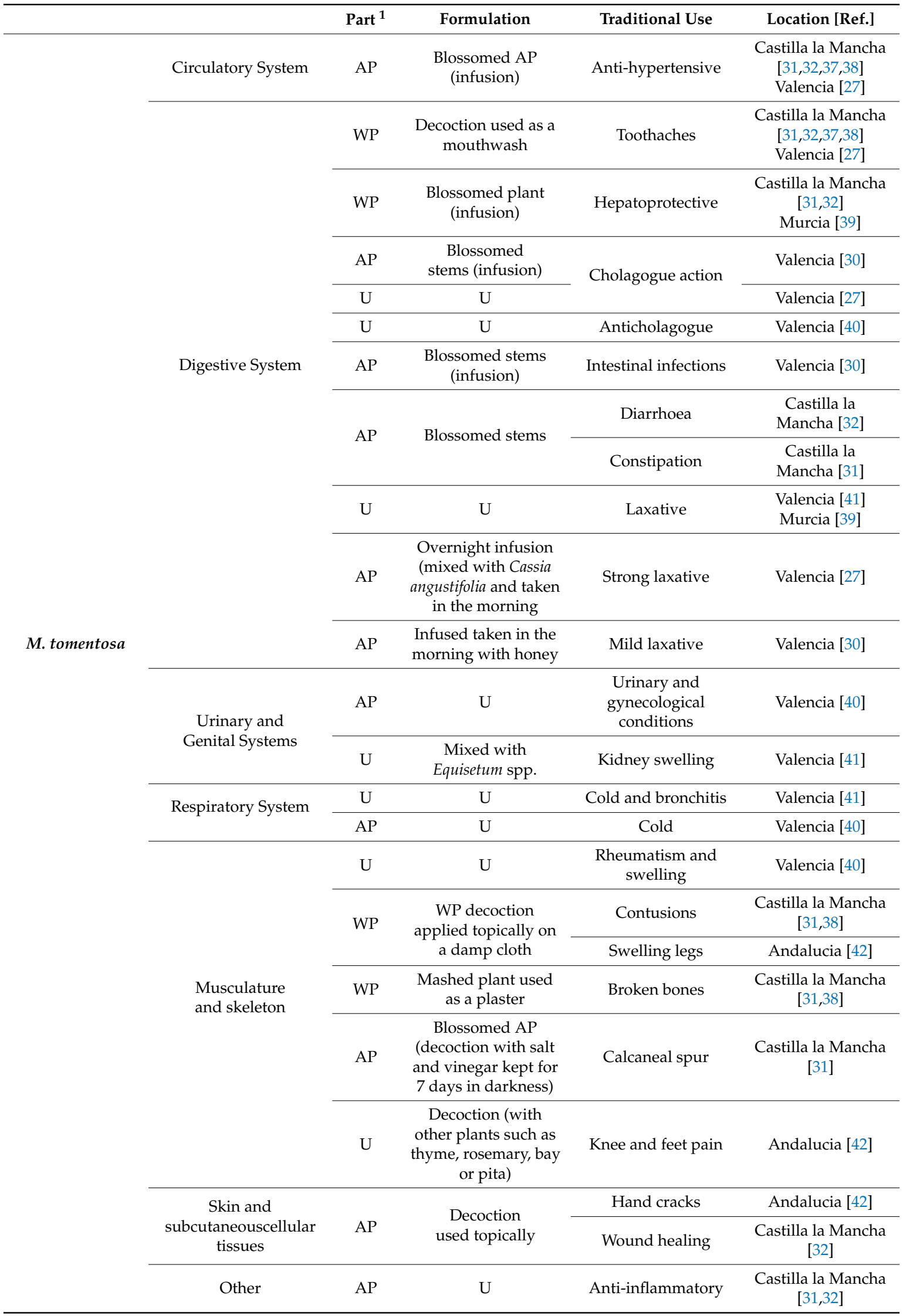

${ }^{1}$ Part used: U, unknown; AP, Aerial part; R, Root; WP, whole plant. 
An infusion of the blossomed aerial parts from M. tomentosa was reported to decrease blood pressure in Castilla la Mancha [31,32,37,38] and Valencia [27]. The same effect has been stated for the other Mercurialis species investigated in this work, but the way the plant was processed is unknown [20]. Another important medicinal use of M. annua/M. ambigua and M. perennis, commonly employed in the Canary Islands, was to decrease blood sugar levels [20].

The use of the four Mercurialis species to treat diseases associated with the respiratory system has been reported throughout Spain. For example, in the Canary Islands, they were used to treat sore throats and lung diseases [35], while in Valencia, cold and bronchitis symptoms were ameliorated with M. tomentosa $[40,41]$.

An interesting use of M. annua/M. ambigua practiced in Navarra was to reduce dark spots on the skin with the application over the affected areas of the fresh parts of the plants macerated in olive oil blended with bee wax [36].

The historical use of Mercurialis spp. to treat gynecological disorders has also been reflected in the Spanish ethnobotanical knowledge. For example, $M$. tomentosa has been used for this aim in Valencia [40]. M. annua/M. ambigua have been used to induce miscarriage in pregnant women in Cataluña [21] and to suppress lactation in the Canary Islands [34].

Finally, the anti-inflammatory activity of M. tomentosa in Castilla la Mancha has been reported in different studies [31,32] and could explain the use of this species in the treatment of rheumatism and swellings [40], contusions [31,38], articular pain [42], and broken bones [31,38], as well as wound healing [32]. In most of the cases, except for broken bones, the decoction of Mercurialis, alone or in combination with some other plants, was used topically.

\subsection{Towards a Validation of the Pharmacological Effects of Mercurialis spp.}

The main phytochemicals present in Mercurialis spp. are presented in Figure 2. They are flavonoids, coumarins, alkaloids, phenolic acids, terpenes and steroids, and miscellaneous compounds, such as simple aromatic constituents and phenolic lipids $[5,14,15,19,43]$. 


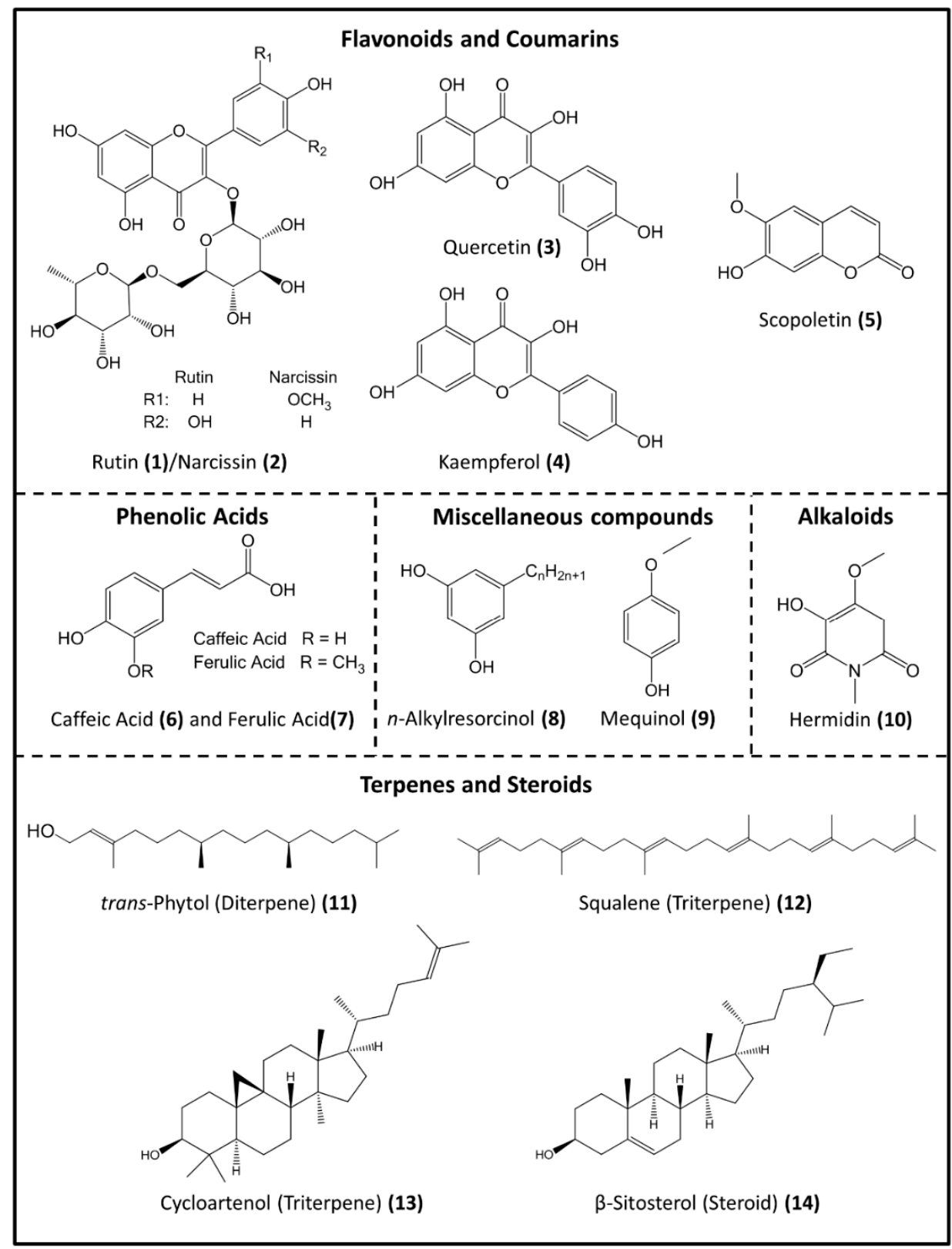

Figure 2. Chemical structures of the main bioactive phytochemicals in Mercurialis spp. (from PubChem [44]).

\subsection{Experimental Studies on Activity}

The chemical composition of Mercurialis spp. and the biological activity of the phytochemicals that could explain the traditional medicinal uses of this plant in Spain are presented in Table 2.

Among the compounds compiled in Table 2, the potential of the flavonoids rutin (1) and narcissin (2) to decrease blood sugar levels [45-47] and blood pressure [48], respectively, are especially remarkable. Another well-demonstrated effect is the use of mequinol (9) to treat skin depigmentation [49-51], compatible with the use of M. annua/M. ambigua described in Navarra as a skin whitening agent [36]. 
Table 2. Biological activity of selected phytochemicals from Mercurialis spp.

\begin{tabular}{|c|c|c|c|}
\hline Chemical Class & Phytochemicals & Biological Activity & Reference \\
\hline \multirow{11}{*}{ Flavonoids } & \multirow{3}{*}{ Rutin (1) } & Spasmolytic & [52] \\
\hline & & Anti-hyperglycemic & [45-47] \\
\hline & & Anti-oxidant & {$[47,53]$} \\
\hline & Narcissin (2) & Anti-hypertensive & [48] \\
\hline & \multirow{3}{*}{ Quercetin (3) } & Spasmolytic & {$[54,55]$} \\
\hline & & Antidiarrhoeal & {$[56]$} \\
\hline & & Anti-hypertensive & [57] \\
\hline & \multirow{4}{*}{ Kaempferol (4) } & Anti-oxidant & [58] \\
\hline & & Anti-inflammatory & [59] \\
\hline & & Anticancer & [60] \\
\hline & & Spasmolytic & [61] \\
\hline \multirow{3}{*}{ Coumarins } & \multirow{3}{*}{ Scopoletin (5) } & Spasmolytic & {$[62]$} \\
\hline & & Anti-inflammatory & {$[63,64]$} \\
\hline & & Hepatoprotective & [65] \\
\hline \multirow{3}{*}{ Phenolic acid } & Caffeic Acid (6) & Anti-oxidant & [66] \\
\hline & \multirow{2}{*}{ Ferulic acid (7) } & Antidiabetic & [67] \\
\hline & & Cholagogue and Choleretic & [68] \\
\hline \multirow{2}{*}{$\begin{array}{c}\text { Phenolic } \\
\text { Lipids }\end{array}$} & \multirow{2}{*}{ n-Alkylresorcinol (8) } & Muscle atrophy prevention & [69] \\
\hline & & Anti-obesity and glucose intolerance suppression & [70] \\
\hline Simple Phenolics & 4-Methoxyphenol (9) & Skin Depigmentation & [49-51] \\
\hline Alkaloids & Hermidin (10) & Not described & - \\
\hline Diterpenes & trans-Phytol (11) & $\begin{array}{c}\text { Aromatase Inhibitor } \\
\text { Treatment of estrogen-dependent cancer }\end{array}$ & [71] \\
\hline \multirow{4}{*}{ Triterpenes } & \multirow{4}{*}{ Squalene (12) } & Anti-hypercholesterolemic & {$[72,73]$} \\
\hline & & Antihypertriglyceridemic & {$[73]$} \\
\hline & & Anti-oxidant & [73] \\
\hline & & Anti-inflammatory & [73] \\
\hline \multirow{4}{*}{ Steroids } & \multirow{3}{*}{ Cycloartenol (13) } & Anti-inflammatory & \multirow{3}{*}{ [74] } \\
\hline & & Antitumor & \\
\hline & & Anti-oxidant & \\
\hline & $\beta$-Sitosterol (14) & $\begin{array}{l}\text { Prevention of Streptococcus pneumoniae } \\
\text { (lung) infection }\end{array}$ & [75] \\
\hline
\end{tabular}

\subsection{In Silico Modelling for Hermidin Target Prediction}

Since no scientifically proven biological activities were found for the alkaloid hermidin, in silico modelling was done using the software Swiss Target Prediction [76]. Computational predictions of bioactive molecule targets based on similarity with known ligands were done to narrow down the number of potential targets and rationalize side effect of molecules. The main results obtained for Homo sapiens are shown in Table 3. From all the targets analyzed, the membrane muscarinic acetylcholine receptors (mAChRs) M1, M2, M3, M4, and M5 showed the highest probability to be hermidin targets. Similar results were obtained for Mus musculus and Ratus norvegicus (data not shown). The mAChRs antagonist action shown for other well-known alkaloids, such as scopolamine and atropine [77], support the result of our computational modelling. 
Table 3. Hermidin targets obtained by computational modelling using Swiss Target Prediction Software.

\begin{tabular}{|c|c|c|c|c|c|c|}
\hline Target & $\begin{array}{l}\text { Common } \\
\text { Name }\end{array}$ & Uniprot ID & ChEMBL ID & Probability* & $\begin{array}{l}\text { \#sim. Cmpds } \\
\text { (3d/2D) }\end{array}$ & Target Class \\
\hline $\begin{array}{l}\text { Muscarinic } \\
\text { acetylcholine } \\
\text { receptor M1 }\end{array}$ & CHRM1 & P11229 & CHEMBL216 & & $1 / 2$ & $\begin{array}{l}\text { Membrane } \\
\text { receptor }\end{array}$ \\
\hline $\begin{array}{l}\text { Muscarinic } \\
\text { acetylcholine } \\
\text { receptor M2 }\end{array}$ & CHRM2 & P08172 & CHEMBL211 & & $1 / 1$ & $\begin{array}{l}\text { Membrane } \\
\text { receptor }\end{array}$ \\
\hline $\begin{array}{l}\text { Muscarinic } \\
\text { acetylcholine } \\
\text { receptor M3 }\end{array}$ & CHRM3 & P20309 & CHEMBL245 & & $1 / 2$ & $\begin{array}{l}\text { Membrane } \\
\text { receptor }\end{array}$ \\
\hline $\begin{array}{l}\text { Muscarinic } \\
\text { acetylcholine } \\
\text { receptor M4 }\end{array}$ & CHRM4 & P08174 & CHEMBL1821 & & $1 / 2$ & $\begin{array}{l}\text { Membrane } \\
\text { receptor }\end{array}$ \\
\hline $\begin{array}{l}\text { Muscarinic } \\
\text { acetylcholine } \\
\text { receptor M5 }\end{array}$ & CHRM5 & P08912 & CHEMBL2035 & & $1 / 2$ & $\begin{array}{l}\text { Membrane } \\
\text { receptor }\end{array}$ \\
\hline
\end{tabular}

\section{Discussion}

Despite their toxicity, Mercurialis spp. have been widely used medicinally since ancient times, although they are relatively underused nowadays. When carrying out this review on the traditional knowledge concerning four Mercurialis species (Mercurialis annua L., Mercurialis ambigua L., Mercurialis perennis L., and Mercurialis tomentosa L.) in Spain, we found a great variety of medicinal uses.

Several studies have been published on the chemical composition of M. annua $[15,43,78]$, $M$. perennis $[5,10,12,14-16,79,80]$, and $M$. tomentosa [19], confirming the presence of a wide variety of phytochemicals in these species (Table S1). Some of them possess some interesting biological activity, which has already been extensively validated scientifically (Table 2). Previous studies on the medicinal uses of Mercurialis spp. and their constituents are detailed below according to distinct body systems.

\subsection{Circulatory System}

M. annua/M. perennis have been used to control blood sugar levels, an effect that can be attributed to the presence of quercetin-3-O-rutinoside (rutin) (3) and ferulic acid (7). The antihyperglycemic properties of rutin (1) have been widely demonstrated, as well as its potential to prevent and treat pathologies associated with diabetes, nephropathy, neuropathy, liver damage, and cardiovascular disorders. The mechanisms proposed for the antihyperglycemic effect of rutin (1) include a decrease in the absorption of carbohydrates, an inhibition of gluconeogenesis, an increase in tissue glucose uptake, a stimulation of the secretion of insulin, and a protection of the Langerhans islets against degeneration [46]. The activity of ferulic acid (7) in type 2 diabetes was demonstrated in high-fat and fructose-induced type 2 diabetic rats, where the blood glucose and serum insulin levels were restored, improving insulin sensitivity and hepatic glycogenesis, inhibiting gluconeogenesis and negative regulators of insulin signaling to maintain normal glucose homeostasis [67].

Another flavonoid component of $M$. annua is isorhamnetin-3-O-rutinoside (narcissin) (2), which could be responsible for the antihypertensive action of this plant, as it has previously demonstrated such an effect [48]. The flavonoid kaempferol (4), which can relax smooth muscles, could also explain the antihypertensive effect [61].

\subsection{Digestive System}

The antidiarrheal effect of Mercurialis spp. described in Castilla la Mancha could rely on the spasmolytic action of the flavonoids rutin (1) and quercetin (3) and of the coumarin scopoletin (5) [52,62]. On the other hand, the extensive use of Mercurialis spp. as laxatives could be explained by the antagonistic actions obtained in some cases by the same plant. An example of this has been reported in 
a recent publication in which the spasmolytic and spasmogenic activity of Punica granatum Linn. were described with high and low doses of plant extracts, respectively [81]. The spasmogenic response seems to be triggered by cholinergic activation, whereas the spasmolytic effect appears to be mediated by the blockade of voltage gated calcium channels. The molecule responsible for the spasmogenic action could be caffeic acid (6), a phenolic acid also present in peach leaves, which also have spasmogenic activity [82].

The cholagogue/anticholagogue action reported for $M$. tomentos $a$ in Valencia is another example of how antagonistic effects can be observed for the same plant. Ferulic acid (7) is categorized as a cholagogue and choleretic compound by the MeSH (Medical Subject Headings) from PubMed [68]. No scientific evidence supporting the anticholagogue effect of any of the phytochemicals from Mercurialis spp. has been found.

The hepatoprotective activity of the blossomed stems of $M$. tomentosa reported in Castilla la Mancha and Murcia could rely on scopoletin (5), only present in this species so far [19]. A recent study has shown a reduction in the level of hepatic lipid accumulation and liver inflammation in diabetic rats treated with scopoletin to the same extent as the antidiabetic drug metformin [65]. In spite of the absence of reports on M. annua/M. ambigua/M. perennis in folk knowledge concerning its liver protective action, the presence of squalene (12) in M. perennis could make this plant a good candidate to treat hepatic disorders, since it has been demonstrated that squalene (12) could accumulate in the liver decreasing the levels of hepatic cholesterol and triglycerides [73]. This could have a beneficial effect on the gallbladder, due to the fact that low cholesterol hepatic levels are necessary to reduce the formation of gallstones [83].

\subsection{Skin}

The treatment of dark spots on the skin using M. annua, as reported in Navarra, could be attributed to the presence of 4-methoxyphenol (mequinol or 4-hydroxyanisole-4-HA-) (9). The latter is a common topical treatment for melasma, commercialized at a concentration of $2 \%$ in combination with $0.01 \%$ tretinoin [49]. It acts as a substrate for tyrosinase and inhibits the formation of melanin precursors [49]. Its role as a tyrosinase substrate also makes 4-HA (9) a promising agent to treat melanoma [84], since 4-HA (9) can be oxidized to 4-methoxycatechol and its o-quinone [84]. The latter is a potent electrophile agent which binds covalently to protein thiols and/or glutathione, leading to melanoma cell death [85]. 4-HA (9) is also used topically to treat depigmentation in patients with vitiligo when extensive body surface areas are unresponsive to repigmentation therapies [51].

\subsection{Respiratory System}

The activity of $M$. perennis against lung infections may be attributed to the sterol $\beta$-sitosterol (14). Indeed, it has been demonstrated that the interaction between $\beta$-sitosterol (14) and pneumolysin, a virulence factor from Streptococcus pneumoniae, affects the ability of $S$. pneumoniae to colonize the lungs [75].

\subsection{Urinary and Genital Systems}

Mercurialis spp. are used traditionally to treat gynecological disorders. A recent study has demonstrated the role of trans-phytol (11), a diterpene present in M. perennis, as an aromatase inhibitor. Aromatase is an enzyme involved in the biosynthesis of estrogens, and aromatase inhibitors are a way to prevent or treat estrogen-mediated carcinogenesis, including breast, ovarian, and endometrial cancers [86]. The presence of trans-phytol (11) in the aerial parts of $M$. perennis suggests that this plant could be important in the prevention or treatment of estrogen-dependent carcinogenesis [71].

The inhibition of estrogens biosynthesis by trans-phytol (11) could also explain the use of M. perennis as an abortive agent, since estrogens are required for the continuation of pregnancy. Besides trans-phytol (11), the aforementioned spasmogenic action of caffeic acid (6) could also play a determinant role in the abortive action of $M$. perennis, since it could be involved in triggering uterine 
contractions needed for the termination of pregnancy. The relation between plants with spasmogenic properties and miscarriage being a well-established feature [87]. Although the spasmogenic action of caffeic acid (6) has not been clearly demonstrated, a previous study showed that another phenolic acid (gallic acid) had a spasmogenic effect [87].

The treatment of urinary and gynecological conditions, such as renal colic and dysmenorrhea reported in Valencia, could also rely on the antispasmodic action of rutin (1), quercetin (3), and scopoletin (5) [88,89].

The relief of menstrual molimina symptoms could rely on the presence of $\beta$-sitosterol (14) (the most abundant phytosterol in M. perennis - $14.2 \%-$ ) and campesterol (2.4\%). A similar action has been demonstrated for Evening Primrose (Oenothera biennis L.) oil, which is widely used as a natural therapy to ease menstrual molimina symptoms. In evening primrose oil, both sterols are involved in inhibiting the release of different proinflammatory mediators [90].

\subsection{Others}

All Mercurialis spp have been used traditionally to treat arthrosis and inflammatory-mediated disorders, although the anti-inflammatory activity is more prominent in $M$. tomentosa. The latter has been employed to relieve rheumatism, swellings toothaches, and for contusions, broken bones, knee and feet pain, and wound healing. The anti-inflammatory properties of $M$. tomentosa could be explained by the presence of scopoletin (5) [19], which has demonstrated anti-inflammatory activity through cytokine suppression $[63,64]$. Other compounds with well-established antioxidant properties and present in Mercurialis spp. that could also contribute to the anti-inflammatory effect of this plant include kaempferol (4), squalene (12), and cycloartenol (13) [58,59,73,74]. Kaempferol (4) (a component of M. perennis) has already demonstrated efficacy in the treatment of arthrosis [59], which is the only anti-inflammatory use reported for M. perennis/M. annua.

Finally, despite the lack of scientific evidence linking the piperidinedione alkaloid hermidin (10) with the medicinal uses of Mercurialis spp., this alkaloid deserves a special mention here. Although there were some suggestions that this compound could be associated with the plant's toxicity, it was the alkaloid pyridine-3-carbonitrile that was identified as the toxic principle in M. annua [15]. Interestingly, in a study made using the Swiss Target Prediction Software $[76,91]$ to predict any possible interaction of hermidin with cellular molecules, we observed that hermidin (10) showed some strong interactions with membrane muscarinic acetylcholine receptors M1, M2, M3, M4, and M5.

The scientific validation of the traditional medicinal uses of Mercurialis spp. presented in this review places this genus in a promising position to suggest further scientific research. This should focus on testing its extracts and all its phytochemicals components for biological activity to provide a direct validation of its medicinal properties as described in traditional Spanish medicine.

In summary, this review contributes to the preservation, documentation, and validation of the traditional medicinal uses of the most prominent Mercurialis spp. from the Iberian Peninsula and lays the foundation for new scientific investigations on this medicinal plant.

\section{Materials and Methods}

A bibliographic search was performed to provide scientific evidence for the medicinal uses of the four Mercurialis species under study. The chemical composition of these plants and the biological activity of the phytochemicals described were established using the following databases: Scopus, Dialnet, Medline, PubMed, ScienceDirect, Google Patents, Google Scholar, and Wiley Online, following a Prisma 2009 flow diagram methodology [92].

The chemical structures of the compounds presented in this work were retrieved from PubChem [44], a database of chemical compounds, maintained by the National Center for Biotechnology Information (NCBI), a component of the National Library of Medicine of the National Institues of Health (NIH). All structures were drawn and edited using the software ChemDraw Professional 17.0 (Perkin Elmer) 
The Swiss Target Prediction Software [76,91], a free webserver to accurately predict the targets of bioactive molecules based on 2D and 3D similarities with known ligands, was used to predict the probable molecular targets of hermidin.

Supplementary Materials: The following are available online at http://www.mdpi.com/2223-7747/8/7/193/s1, Table S1: Chemical composition of Mercurialis spp.

Author Contributions: Conceptualization, T.R.-T. and J.B.-S.; methodology, T.R.-T.; software, T.R.-T.; investigation, J.B.-S., T.R.-T. and M.P.H.-V.; data curation, J.B.-S., T.R.-T. and M.P.H.-V.; writing-original draft preparation, M.P.H.-V.; writing—review and editing, T.R.-T. and J.B.-S.; visualization, F.M.-V.; supervision, T.R.-T. and F.M.-V.; project administration, T.R.-T.; funding acquisition, T.R.-T.

Funding: This research was funded by the Consejería de Economía e Infraestructuras (Junta de Extremadura) and Fondo Europeo de Desarrollo regional (FEDER), through the grant "Valorización de la biodiversidad vegetal del espacio protegido" ZIR Sierra Grande de Hornachos "como fuente de innovación para el desarrollo (IB16003)". J.B.-S. and M.P.H.-V. are post-doctoral researchers funded by the same grant.

Acknowledgments: We are grateful to Professor Godfrey Smith for his helpful discussion and critical reading of the manuscript and to Francisco Centeno Velazquez for his help and advice on how to use the Swiss Target Prediction Software.

Conflicts of Interest: The authors declare no conflict of interest.

\section{References}

1. Güemes, J.; Mercurialis, L. Flora Iberica Volume VIII; CSIC: Madrid, Spain, 1977; pp. 201-210.

2. García-Ortega, P.; Belmonte Soler, J. Polinosis: Polen y Alergia (Capítulo Mercurial). In Polinosis: Polen y Alergia; MRA, Ed.; MRA: Port Louis, Mauritius, 2002; pp. 83-89.

3. Berger, F. Handbuch der Drogenkunde, Verlag für Medizinische Wissenschaften; Wilhelm Maudrich Verlag: Viena, Austria, 1954; pp. 348-351.

4. Madaus, G. Lehrbuch der Biologischen Heilmittel, 2nd ed.; Olms Georg AG: Hildesheim, Germany, 1979.

5. Lorenz, P.; Hradecky, M.; Berger, M.; Bertrams, J.; Meyer, U.; Stintzing, F.C. Lipophilic constituents from aerial and root parts of Mercurialis perennis L. Phytochem. Anal. 2010, 21, 234-245. [CrossRef] [PubMed]

6. Bismarck, R.; Floehr, W. Poisoning with Mercurialis perennis in a grazing cow herd. Short communication from practice. Dtsch. Tierarztl. Wochenschr. 1974, 81, 433-434.

7. Watson, P.J. Suspected dog's mercury (Mercurialis perennis) poisoning in cattle. Vet. Rec. 1988, 142, 116-117. [CrossRef]

8. Blanco-Salas, J.; Ruiz-Téllez, T.; Vázquez-Pardo, F.M. Mercurialis annua L. y M. ambigual L. fil. In Inventario Español de los Conocimientos Tradicionales Relativos a la Biodiversidad; Ministerio de Agricultura, Ed.; Alimentación y Medio Ambiente Secretaría General Técnica Centro de Publicaciones: Madrid, Spain, 2018; pp. 272-275.

9. Blanco-Salas, J.; Ruiz-Téllez, T.; Vázquez-Pardo, F.M. Mercurialis Tomentosa L. In Inventario Español de los Conocimientos Tradicionales Relativos a la Biodiversidad; Ministerio de Agricultura, Ed.; Secretaría General Técnica Centro de Publicaciones: Madrid, Spain, 2018; pp. 276-278.

10. Berger, M.; Hradecky, M.; Bertrams, J.; Stintzing, F.; Lorenz, P.; Meyer, U. Investigations on alkaloids and lipid constituents from Mercurialis perennis. Planta Med. 2009, 75, PJ1.

11. Bertrams, J.; Lorenz, P.; Stintzing, F.; Knoedler, M.; Meyer, U. First report of n-alkylresorcinol occurrence in the Euphorbiaceae family: Mercurialis perennis L. Z. Für Phyther. 2009, 30, 4-5.

12. Lorenz, P.; Knödler, M.; Bertrams, J.; Berger, M.; Meyer, U.; Stintzing, F.C. N-alkylresorcinol occurrence in Mercurialis perennis L. (Euphorbiaceae). Z. Fur Naturforsch. Sect. C J. Biosci. 2010, 65, 174-179. [CrossRef]

13. Bertrams, J.; Meyer, U.; Duckstein, S.; Lorenz, P.; Stintzing, F. Conversion of hydrophilic constituents from Mercurialis perennis L. by lactic acid fermentation. Planta Med. 2010, 76, 1286.

14. Lorenz, P.; Stintzing, F.C.; Meyer, U.; Conrad, J.; Berger, M.; Duckstein, S.; Bertrams, J. Investigations into the Phenolic Constituents of Dog's Mercury (Mercurialis perennis L.) by LC-MS/MS and GC-MS analyses. Phytochem. Anal. 2011, 23, 60-71. [CrossRef]

15. Lorenz, P.; Duckstein, S.; Conrad, J.; Knödler, M.; Meyer, U.; Stintzing, F.C. An approach to the chemotaxonomic differentiation of two European Dog's mercury species: Mercurialis annua L. and M. perennis L. Chem. Biodivers. 2012, 9, 282-297. [CrossRef] 
16. Lorenz, P.; Duckstein, S.; Conrad, J.; Kammerer, D.R.; Stintzing, F.C. Chemistry of Hermidin, the Main Alkaloid of the Medicinal plant Mercurialis perennis L. (Euphorbiaceae). Planta Med. 2013, 79, 1245-1246. [CrossRef]

17. Lorenz, P.; Stintzing, F. Converting the molecular framework of medicinal plant constituents: A fermented Mercurialis extract with wound-healing activity. Planta Med. 2013, 79, SL43. [CrossRef]

18. Lorenz, P.; Heinrich, M.; Kammerer, D.; Stintzing, F. 4-Methyl-1-alkylresorcinols, novel chemotaxonomic markers from the Spanish medicinal plant Mercurialis tomentosa L. Planta Med. 2016, 81, S1-S381. [CrossRef]

19. Lorenz, P.; Heinrich, M.; Conrad, J.; Heller, A.; Stintzing, F.C.; Kammerer, D.R. Comprehensive Characterisation of n-Alkylresorcinols and Other Lipid Constituents of Mercurialis tomentosa L. from Alicante, Spain. Chem. Biodivers. 2017, 14, 1-12. [CrossRef] [PubMed]

20. Gil Gonzalez, J.; Peña Hernadez, M.; Niz Torres, R. Usos Culturales de las Yerbas en Los Campos de Lanzarote. Bases Orales Para la Reconstrucción del Conocimiento Etnobotánico Tradicional; Asociación Para el Desarrollo Rural de Lanzarote (ADERLAN): Arrecife de Lanzarote, Spain, 2009.

21. Bonet, M.A. Estudi Etnobotànic del Montseny; Universitat de Barcelona: Barcelona, Spain, 2001.

22. Blanco Castro, E.; Cuadrado Prieto, C. Etnobotánica en Extremadura. Estudio de La Calabria y La Siberia Extremeñas; Emilio Blanco y CEP Alcoba de los Montes: Madrid, Spain, 2000.

23. Viera y Clavijo, J. De Diccionario de Historia Natural de las Islas Canarias, o Índice Alfabético Descriptivo de Sus Tres Reinos Animal, Vegetal y Mineral; Imp. de la Verdad: Las Palmas de Gran Canaria, Spain, 1866.

24. Reyes Prosper, E. Las Estepas de España y su Vegetación; Casa Real: Madrid, Spain, 1915.

25. Parada, M. Estudi etnobotànic de L'Alt Empordà; Universitat de Barcelona: Barcelona, Spain, 2008.

26. Villar Perez, L.; Palacin Latorre, J.M.; Calvo Eito, C.; Gomez Garcia, D.; Monserrat-Marti, G. Plantas Medicinales del Pirineo Aragonés y Demás Tierras Oscenses; CSIC, Diputación de Huesca: Huesca, Spain, 1987.

27. Mulet Pascual, L. Estudio Etnobotánico de la Provincia de Castellón; Diputación de Castellón: Castellón de la Plana, Spain, 1991.

28. Rigat, M. Estudi Etnobotànic de la Vall de Camprodon (Alta Vall del Ter, Pirineus); Universitat de Barcelona: Barcelona, Spain, 2005.

29. Carrio, E.; Rigat, M.; Garnatje, T.; Mayans, M.; Parada, M.; Valles, J. Plant Ethnoveterinary Practices in Two Pyrenean Territories of Catalonia (Iberian Peninsula) and in Two Areas of the Balearic Islands and Comparison with Ethnobotanical Uses in Human Medicine. Evid. Based Complement. Altern. Med. 2012. [CrossRef] [PubMed]

30. Conca Ferrus, A.; Oltra i Benavent, J.E. Plantes Medicinals y Comestibles; Caixa d'Estalvis i Monte de Pietat d'Ontinyent: Valencia, Spain, 2005.

31. Verde, A.; Rivera, D.; Fajardo, J.; Obón, C.; Cebrián, F. Guía de las Plantas Medicinales de Castilla-La Mancha (y Otros Recursos de Uso Tradicional); Altabán: Albacete, Spain, 2008.

32. Rivera, D.; Alcaraz, F.; Verde, A.; Fajardo, J.; Obón, C. Las Plantas en la Cultura Popular. Enciclopedia Divulgativa de la Historia Natural de Jumilla-Yecla; Caja de Ahorros del Mediterráneo: Catarroja, Spain; Sociedad Mediterránea de Historia Natural: Murcia, Spain, 2008.

33. Moll Marques, M. Les Plantes a Menorca: Noms i Usos. Col-Lecció Recerca 10; D’Estudis, I.M., Ed.; Institut Menorqui d’Estudis: Mahón, Spain, 2005.

34. Alvarez Escobar, A. Contribución al Estudio Etnobotánico de la Isla de Tenerife; Universidad de la Laguna: San Cristóbal de La Laguna, Spain, 2011.

35. Perera López, J. Los Nombres Comunes de Plantas, Animales y Hongos de el Hierro; Academia canaria de la Lengua: Las Palmas, Spain, 2006; Volume 8.

36. Akerreta, S.; Calvo, M.I.; Cavero, R.Y. Sabiduría Popular y Plantas Curativas (Recopilación Extraida de un Estudio Etnobotánico en Navarra); Ediciones I: Madrid, Spain, 2013.

37. Verde, A.; Rivera, D.; Obón, C. Etnobotánica en las Sierras de Segura y Alcaraz: Las Plantas y el Hombre.; Instituto de Estudios Albacetenses: Albacete, Spain, 1998.

38. Verde, A. Estudio Etnofarmacológico de Tres Áreas de Montaña de Castilla-La Mancha; Universidad de Murcia: Murcia, Spain, 2002.

39. Rivera, D.; Obón, C.; Cano, F.; Robledo, A. Introducción al Mundo de las Plantas Medicinales en Murcia; Ayuntamiento de Murcia: Murcia, Spain, 1994. 
40. Belda, A.; Zaragozí, B.; Belda, I.; Martínez, J.; Seva, E. Traditional knowledge of medicinal plants in the Serra de Mariola Natural Park, South-Eastern Spain. Afr. J. Tradit. Complement. Altern. Med. 2013, 10, $299-309$. [CrossRef]

41. Pellicer, J. Costumari Botànic. Recerques Etnobotàniques a les Comarques Centrals Valencianes; Edicions del Bullent: Valencia, Spain, 2004; Volume 2.

42. Fernández Ocaña, A. Estudio Etnobotánico en el Parque Natural de las Sierras de Cazorla, Segura y Las Villas. Investigación Química de un Grupo de Especies Interesantes; Universidad de Jaén: Jaen, Spain, 2000.

43. Aquino, R.; Behar, I.; D’agostino, M.; De Simone, F.; Schettino, O.; Pizza, C. Phytochemical investigation on Mercurialis annua. Biochem. Syst. Ecol. 1987, 15, 667-669. [CrossRef]

44. PubChem. Available online: https://pubchem.ncbi.nlm.nih.gov/ (accessed on 28 March 2019).

45. Hosseinzadeh, H.; Nassiri-Asl, M. Review of the protective effects of rutin on the metabolic function as an important dietary flavonoid. J. Endocrinol. Investig. 2014, 37, 783-788. [CrossRef] [PubMed]

46. Ghorbani, A. Mechanisms of antidiabetic effects of flavonoid rutin. Biomed. Pharmacother. 2017, 96, 305-312. [CrossRef] [PubMed]

47. Tanko, Y.; Salisu, A.I.; Mohammed, K.A.; Musa, S.A.; Jimoh, A.; Yusuf, R. Anti-hyperglycaemic Effects of Rutin on Blood Glucose, Oxidative Stress Biomarkers and Lipid Peroxidation in Alloxan-induced Hyperglycaemic Wistar Rats. Niger. J. Physiol. Sci. 2017, 32, 91-96. [PubMed]

48. Chen, L.F.; Wang, G.X.; Li, Q.A.; Liu, G.H. Comparison of effects of narcissin and ligustrazin on cardiac hemodynamics. Zhongguo Yao Li Xue Bao 1987, 8, 123-127. [PubMed]

49. Bandyopadhyay, D. Topical treatment of melasma. Indian J. Dermatol. 2010, 54, 303. [CrossRef]

50. Rossi, A.M.; Perez, M.I. Treatment of hyperpigmentation. Facial Plast. Surg. Clin. 2011, 19, 313-324. [CrossRef] [PubMed]

51. Grimes, P.E.; Nashawati, R. Depigmentation Therapies for Vitiligo. Dermatol. Clin. 2017, 35, $219-227$. [CrossRef] [PubMed]

52. Cimanga, R.K.; Mukenyi, P.N.; Kambu, O.K.; Tona, G.L.; Apers, S.; Totté, J.; Pieters, L.; Vlietinck, A.J. The spasmolytic activity of extracts and some isolated compounds from the leaves of Morinda morindoides (Baker) Milne-Redh. (Rubiaceae). J. Ethnopharmacol. 2010, 127, 215-220. [CrossRef] [PubMed]

53. Saleh, A.; ElFayoumi, H.M.; Youns, M.; Barakat, W. Rutin and orlistat produce antitumor effects via antioxidant and apoptotic actions. Naunyn. Schmiedeb. Arch. Pharmacol. 2019, 392, 165-175. [CrossRef] [PubMed]

54. Ventura-Martínez, R.; Angeles-Lopez, G.E.; Rodriguez, R.; Gonzalez-Trujano, M.E.; Deciga-Campos, M. Spasmolytic effect of aqueous extract of Tagetes erecta L. flowers is mediated through calcium channel blockade on the guinea-pig ileum. Biomed. Pharmacother. 2018, 103, 1552-1556. [CrossRef]

55. Morales, M.A.; Tortoriello, J.; Meckes, M.; Paz, D.; Lozoya, X. Calcium-antagonist effect of quercetin and its relation with the spasmolytic properties of Psidium guajava L. Arch. Med. Res. 1994, 25, 17-21. [PubMed]

56. Zhang, W.J.; Chen, B.T.; Wang, C.Y.; Zhu, Q.H.; Mo, Z.X. Mechanism of quercetin as an antidiarrheal agent. Di Yi Jun Yi Da Xue Xue Bao 2003, 23, 1029-1031.

57. Morales, M.A.; Lozoya, X. Calcium-antagonist effects of quercetin on aortic smooth muscle. Planta Med. 1994, 60, 313-317. [CrossRef]

58. Imran, M.; Rauf, A.; Shah, Z.A.; Saeed, F.; Imran, A.; Arshad, M.U.; Ahmad, B.; Bawazeer, S.; Atif, M.; Peters, D.G.; et al. Chemo-preventive and therapeutic effect of the dietary flavonoid kaempferol: A comprehensive review. Phytother. Res. 2019, 33, 263-275. [CrossRef]

59. Devi, K.P.; Malar, D.S.; Nabavi, S.F.; Sureda, A.; Xiao, J.; Nabavi, S.M.; Daglia, M. Kaempferol and inflammation: From chemistry to medicine. Pharmacol. Res. 2015, 99, 1-10. [CrossRef] [PubMed]

60. Chen, A.Y.; Chen, Y.C. A review of the dietary flavonoid, kaempferol on human health and cancer chemoprevention. Food Chem. 2013, 138, 2099-2107. [CrossRef] [PubMed]

61. MokhtariZaer, A.; Khazdair, M.R.; Boskabady, M.H. Smooth muscle relaxant activity of Crocus sativus (saffron) and its constituents: Possible mechanisms. Avicenna J. Phytomed. 2015, 5, 365-375.

62. Oliveira, E.J.; Romero, M.A.; Silva, M.S.; Silva, B.A.; Medeiros, I.A. Intracellular calcium mobilization as a target for the spasmolytic action of scopoletin. Planta Med. 2001, 67, 605-608. [CrossRef] [PubMed]

63. Kim, H.J.; Jang, S.I.; Kim, Y.J.; Chung, H.T.; Yun, Y.G.; Kang, T.H.; Jeong, O.S.; Kim, Y.C. Scopoletin suppresses pro-inflammatory cytokines and PGE2 from LPS-stimulated cell line, RAW 264.7 cells. Fitoterapia 2004, 75, 261-266. [CrossRef] 
64. Moon, P.D.; Lee, B.H.; Jeong, H.J.; An, H.J.; Park, S.J.; Kim, H.R.; Ko, S.G.; Um, J.Y.; Hong, S.H.; Kim, H.M. Use of scopoletin to inhibit the production of inflammatory cytokines through inhibition of the IkappaB/NF-kappaB signal cascade in the human mast cell line HMC-1. Eur. J. Pharmacol. 2007, 555, 218-225. [CrossRef]

65. Choi, R.Y.; Ham, J.R.; Lee, H.I.; Cho, H.W.; Choi, M.S.; Park, S.K.; Lee, J.; Kim, M.J.; Seo, K.I.; Lee, M.K. Scopoletin Supplementation Ameliorates Steatosis and Inflammation in Diabetic Mice. Phytother. Res. 2017, 31, 1795-1804. [CrossRef]

66. Kono, Y.; Kobayashi, K.; Tagawa, S.; Adachi, K.; Ueda, A.; Sawa, Y.; Shibata, H. Antioxidant activity of polyphenolics in diets: Rate constants of reactions of chlorogenic acid and caffeic acid with reactive species of oxygen and nitrogen. Biochim. Biophys. Acta Gen. Subj. 1997, 1335, 335-342. [CrossRef]

67. Narasimhan, A.; Chinnaiyan, M.; Karundevi, B. Ferulic acid exerts its antidiabetic effect by modulating insulin-signalling molecules in the liver of high-fat diet and fructose-induced type-2 diabetic adult male rat. Appl. Physiol. Nutr. Metab. 2015, 40, 769-781. [CrossRef]

68. Medical Subject Headings (MeSH). Available online: https://www.ncbi.nlm.nih.gov/mesh/82002756 (accessed on 16 March 2019).

69. Hiramoto, S.; Yahata, N.; Saitoh, K.; Yoshimura, T.; Wang, Y.; Taniyama, S.; Nikawa, T.; Tachibana, K.; Hirasaka, K. Dietary supplementation with alkylresorcinols prevents muscle atrophy through a shift of energy supply. J. Nutr. Biochem. 2018, 61, 147-154. [CrossRef]

70. Oishi, K.; Yamamoto, S.; Itoh, N.; Nakao, R.; Yasumoto, Y.; Tanaka, K.; Kikuchi, Y.; Fukudome, S.; Okita, K.; Takano-Ishikawa, Y. Wheat Alkylresorcinols Suppress High-Fat, High-Sucrose Diet-Induced Obesity and Glucose Intolerance by Increasing Insulin Sensitivity and Cholesterol Excretion in Male Mice. J. Nutr. 2014, 145, 199-206. [CrossRef]

71. Guo, J.; Yuan, Y.; Lu, D.; Du, B.; Xiong, L.; Shi, J.; Yang, L.; Liu, W.; Yuan, X.; Zhang, G.; et al. Two natural products, trans-phytol and (22E)-ergosta-6,9,22-triene-3 $\beta, 5 \alpha, 8 \alpha$-triol, inhibit the biosynthesis of estrogen in human ovarian granulosa cells by aromatase (CYP19). Toxicol. Appl. Pharmacol. 2014, 279, 23-32. [CrossRef]

72. Kelly, G.S. Squalene and its potential clinical uses. Altern. Med. Rev. 1999, 4, 29-36.

73. Lou-Bonafonte, J.M.; Martínez-Beamonte, R.; Sanclemente, T.; Surra, J.C.; Herrera-Marcos, L.V.; Sanchez-Marco, J.; Arnal, C.; Osada, J. Current Insights into the Biological Action of Squalene. Mol. Nutr. Food Res. 2018, 62, e1800136. [CrossRef]

74. Zhang, Z.L.; Luo, Z.L.; Shi, H.W.; Zhang, L.X.; Ma, X.J. Research advance of functional plant pharmaceutical cycloartenol about pharmacological and physiological activity. Zhongguo Zhong Yao Za Zhi 2017, 42, $433-437$.

75. Li, H.; Zhao, X.; Wang, J.; Dong, Y.; Meng, S.; Li, R.; Niu, X.; Deng, X. $\beta$-sitosterol interacts with pneumolysin to prevent Streptococcus pneumoniae infection. Sci. Rep. 2015, 5, 1-9. [CrossRef]

76. Gfeller, D.; Michielin, O.; Zoete, V. Shaping the interaction landscape of bioactive molecules. Bioinformatics 2013, 29, 3073-3079. [CrossRef]

77. Svoboda, J.; Popelikova, A.; Stuchlik, A. Drugs interfering with muscarinic acetylcholine receptors and their effects on place navigation. Front. Psychiatry 2017, 8, 1-11. [CrossRef] [PubMed]

78. Ostrozhenkova, E.; Eylert, E.; Schramek, N.; Golan-Goldhirsh, A.; Bacher, A.; Eisenreich, W. Biosynthesis of the chromogen hermidin from Mercurialis annua L. Phytochemistry 2007, 68, 2816-2824. [CrossRef] [PubMed]

79. Lorenz, P.; Conrad, J.; Felenda, J.; Meyer, U.; Stintzing, F. Evaluation of aqueous fermented extracts from Mercurialis perennis with respect to its chemical constituents and wound healing activity. ResearchGate 2012. [CrossRef]

80. Lorenz, P.; Conrad, J.; Stintzing, F.C. Metabolic fate of depsides and alkaloid constituents in aqueous extracts from Mercurialis perennis L. during fermentation. Chem. Biodivers. 2013, 10, 1706-1723. [CrossRef] [PubMed]

81. Ali, N.; Jamil, A.; Shah, S.W.A.; Shah, I.; Ahmed, G. Spasmogenic and spasmolytic activity of rind of Punica granatum Linn. BMC Complement. Altern. Med. 2017, 17, 1-7. [CrossRef] [PubMed]

82. Gilani, A.H.; Aziz, N.; Ali, S.M.; Saeed, M. Pharmacological basis for the use of peach leaves in constipation. J. Ethnopharmacol. 2000, 73, 87-93. [CrossRef]

83. Wang, H.H.; Portincasa, P.; Wang, D.Q. Molecular pathophysiology and physical chemistry of cholesterol gallstones. Front. Biosci. 2008, 13, 401-423. [CrossRef] [PubMed]

84. Moridani, M.Y. Biochemical basis of 4-hydroxyanisole induced cell toxicity towards B16-F0 melanoma cells. Cancer Lett. 2006, 243, 235-245. [CrossRef] [PubMed]

85. Land, E.J.; Cooksey, C.J.; Riley, P.A. Reaction kinetics of 4-methoxy ortho benzoquinone in relation to its mechanism of cytotoxicity: A pulse radiolysis study. Biochem. Pharmacol. 1990, 39, 1133-1135. [CrossRef] 
86. Bulun, S.E.; Lin, Z.; Imir, G.; Amin, S.; Demura, M.; Yilmaz, B.; Martin, R.; Utsunomiya, H.; Thung, S.; Gurates, B.; et al. Regulation of aromatase expression in estrogen-responsive breast and uterine disease: From bench to treatment. Pharmacol. Rev. 2005, 57, 359-383. [CrossRef] [PubMed]

87. Mawoza, T.; Tagwireyi, D.; Nhachi, C. Spasmogenic effects of Sclerocarya birrea stem bark aqueous extract on rat isolated uterine horns. J. Ethnopharmacol. 2015, 164, 129-135. [CrossRef]

88. Golzari, S.E.; Soleimanpour, H.; Rahmani, F.; Mehr, N.Z.; Safari, S.; Heshmat, Y.; Bakhtavar, H.E. Therapeutic Approaches for Renal Colic in the Emergency Department: A Review Article. Anesth. Pain. Med. 2014, 4, e16222. [CrossRef]

89. Romm, A.; Clare, B.; Stansbury, J.E.; Ryan, L.; Trickey, R.; Lee, L.; Hywood, A.J. CHAPTER 5-Menstrual Wellness and Menstrual Problems. In Botanical Medicine for Women's Health; Churchill Livingstone: London, UK, 2010; pp. 97-185, ISBN 978-0-443-07277-2.

90. Monserrat-de la Paz, S.; Fernández-Arche, A.; Angel-Martín, M.; García-Giménez, M.D. The sterols isolated from Evening Primrose oil modulate the release of proinflammatory mediators. Phytomedicine 2012, 19, 1072-1076. [CrossRef]

91. Gfeller, D.; Grosdidier, A.; Wirth, M.; Daina, A.; Michielin, O.; Zoete, V. SwissTargetPrediction: A web server for target prediction of bioactive small molecules. Nucleic Acids Res. 2014, 42, 32-38. [CrossRef] [PubMed]

92. Moher, D.; Liberati, A.; Tetzlaff, J.; Altman, D.G.; Altman, D.; Antes, G.; Atkins, D.; Barbour, V.; Barrowman, N.; Berlin, J.A.; et al. Preferred reporting items for systematic reviews and meta-analyses: The PRISMA statement (Chinese edition). J. Chin. Integr. Med. 2009, 7, 889-896. [CrossRef]

(C) 2019 by the authors. Licensee MDPI, Basel, Switzerland. This article is an open access article distributed under the terms and conditions of the Creative Commons Attribution (CC BY) license (http://creativecommons.org/licenses/by/4.0/). 